\title{
Pore Structures and Reservoir Characteristics of Volcanic Rocks in the Carboniferous Batamayineishan Formation in the Shuangjingzi Area, Eastern Junggar Basin (Western China)
}

Rudarsko-geološko-naftni zbornik

(The Mining-Geology-Petroleum Engineering Bulletin) UDC: 552.1

DOI: 10.17794/rgn.2021.5.10

Original scientific paper

\author{
Masab Ali'; Bian Weihua ${ }^{2}$; Yang Kaikai'; Muhammad Sabeh Khan Panni ${ }^{4}$ \\ ${ }^{1}$ College of Earth Sciences, Jilin University, Jianshe Str. 2199, Changchun, 130061, China \\ ${ }^{2}$ College of Earth Sciences, Jilin University, Jianshe Str. 2199, Changchun, 130061, China \\ ${ }^{3}$ College of Earth Sciences, Jilin University, Jianshe Str. 2199, Changchun, 130061, China \\ ${ }^{4}$ College of Earth Resource, China University of Geosciences, 388 Lumo Road, Wuhan, 430074, Hubei, China
}

\begin{abstract}
Junggar Basin is one of the largest sedimentary basins in Northwest China. Carboniferous oil and gas fields have been found in different areas in the eastern part of the Junggar Basin on a large scale, indicating that the Carboniferous rocks of the Junggar Basin have a huge potential for oil and gas exploration. This study focuses on the Batamayineishan Formation in the eastern part of the Junggar Basin, which contains volcanic rocks and pyroclastic rocks, aiming to investigate the reservoir characteristics and to identify the formation mechanism of the rocks of this formation. The majority of the existent reservoir space in the volcanic rocks of the Batamayineishan Formation is dominated by secondary pores and fractures. Using the methods of petrography, pressure-controlled mercury injection (PMI), and electron probe microanalysis (EPMA), the reservoir characteristics and diagenetic history of the volcanic rocks of the Batamayineishan Formation in the Shuangjingzi area were studied. A theoretical framework is established to provide favorable guidance for exploring Carboniferous volcanic rocks in the Junggar Basin. The results of mercury injection indicate that the average pore throat radius and porosity of the volcanic rocks are $0.068 \mu \mathrm{m}$ and $6.62 \%$, respectively. Permeability remains stable and does not show a significant change with an increase in porosity. Despite the high porosity, the permeability is relatively low, reflecting isolated and non-connected primary pores. The average value of permeability is relatively low $\left(0.424 \times 10^{-3}\right.$ $\mu \mathrm{m}^{2}$ ), which typically suggests narrow micro-throats. Primary gas pores fill and develop amygdales on a large scale. In addition, the dissolution pores developed by dissolution and alteration also compensated for the decrease in the original gas pore volume.
\end{abstract}

Keywords:

Junggar Basin; Batamayineishan Formation; volcanic reservoir; pore structures; diagenesis; pore filling

\section{Introduction}

Volcanic reservoirs have been found in many locations worldwide (Nakata, 1981; Petford and McCaffrey, 2003; Sruoga and Rubinstein et al., 2004; Sruoga and Rubinstein, 2007; Lenhardt and Götz, 2011; Barreto and de Lima et al., 2017; Navelot and Géraud et al, 2018). Volcanic reservoirs are a common occurrence in the sedimentary basins of China, and the first volcanic hydrocarbon reservoir was discovered in 1957, the northwestern periphery of the Junggar Basin (Zou and Zhao et al., 2008). Since the discovery of the first volcanic reservoir in the northwestern margin of the Junggar Basin, volcanic oil and gas reservoirs have gained significant attention and have been reported in many petroliferous basins in China, such as the Junggar, Sichuan, Bohai Bay, Santanghu, Songliao, and Hailer basins (Yang and Hou et al., 2017; Sun and Zhong et al.,

Corresponding author: Weihua Bian

WeihuaBIAN@jlu.edu.cn
2018; Sun and Cao et al., 2018; Zheng and Sun et al., 2018). Reservoir volcanic rocks range from basalt to andesite or rhyolite formed over different geological ages (Zou, 2013; Wang and Chen, 2015). Volcanic oil and gas reservoir research focuses on reservoir types, formation mechanisms, and the main controlling factors (Zheng and Sun et al., 2018). Previous studies have suggested that primary and secondary pores typically control the reservoir space in volcanic rocks. Primary pores formed by welding, volatile outgassing, deuteric recrystallization, and autoclastic brecciation may enhance the porosity and permeability (references). Secondary processes, such as compaction and alteration, could destroy primary pores; however, several secondary processes may contribute positively to enhancing reservoir quality by generating secondary pore systems, such as dissolution during the burial period, weathering, and leaching. Fractures and cracks coupled with pores play a key role in developing oil and gas reservoirs on a large scale (Sruoga and Rubinstein et al., 2004; Chen 


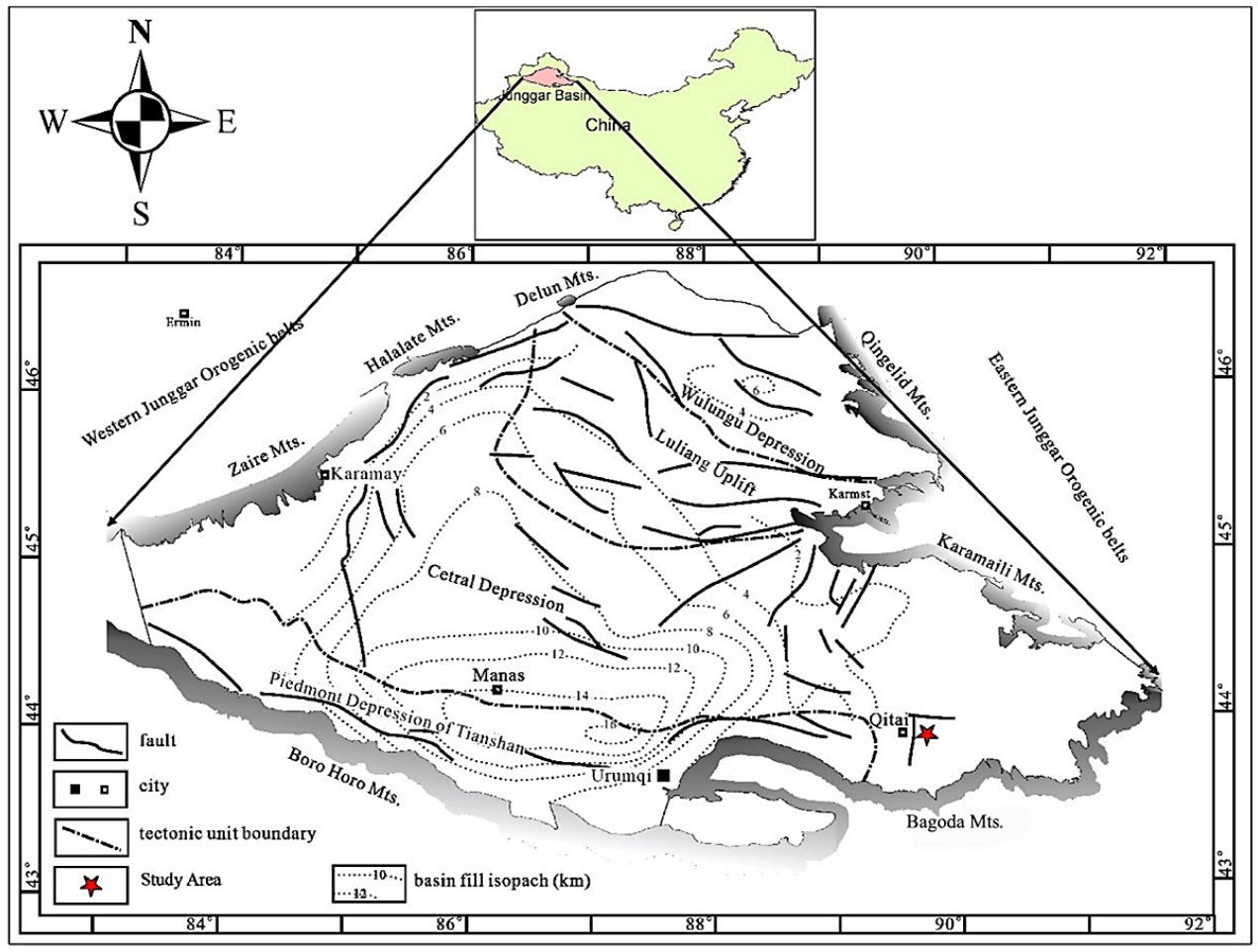

Figure 1: Simplified structural map of Junggar Basin showcasing the distribution of different tectonic units and major faults, as well as the location of the study area (modified from Tang et al., 1997; Xu et al., 20o1; Bian et al., 2010)

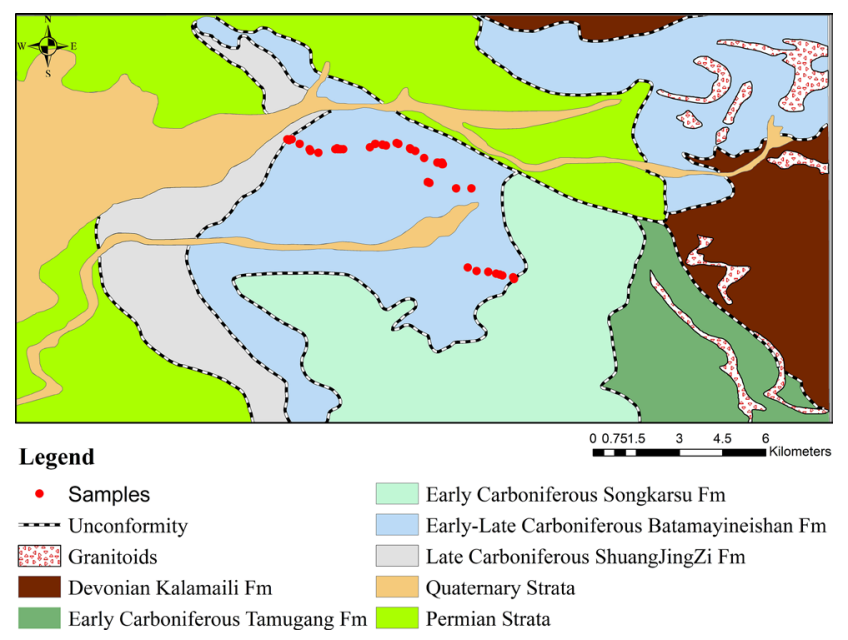

Figure 2 Simplified geological map of the Shuangjingzi area showcasing the distribution of Carboniferous volcanic rocks and samples at the location.

and Wang et al., 2017; Huang and Hu et al., 2019). The Shuangjingzi region of the eastern Junggar Basin contains numerous Carboniferous volcanic rocks, and outcrops which are well exposed along this area (Du and Han et al., 2017). The Carboniferous volcanic rocks of the Batamayineishan Formation in the Dixi area contain various types of fracture fillings. A model has been developed that presents different stages of formation and evolution of fracture fillings (Feng and Liu et al., 2019). The volcanic reservoirs of the Batamayi- neishan Formation in the eastern part of the Junggar Basin have been studied using different methods and from different perspectives, such as lithology, lithofacies, reservoir space, and diagenesis, achieving fruitful results (Xiao and Zhang et al., 2011; Su and Zheng et al., 2012; Yang and He et al., 2012; Cui and Zhang et al., 2013; Zhang and Guo et al., 2015; Shi and Sun et al., 2017). This study focuses on the lithology, physical properties, reservoir space type, pore structure type and pore infilling of the Carboniferous Batamayineishan Formation in the Shuangjingzi area of the Junggar Basin, eastern China. The main objective of this study is to investigate the lithological characteristics by petrographic and outcrop observations and describe pore types and pore structures controlling reservoir space. This study provides new insights for understanding volcanic reservoir spaces and improving the quality of the Batamayineishan Formation volcanic reservoir.

\subsection{Geological setting}

The Junggar Basin is located in the north of the Xinjiang Uygur Autonomous Region, northwestern China, with a basin area of approximately $136,000 \mathrm{~km}^{2}$. Geologically, the Junggar Basin is located in the central part of the Central Asian orogenic belt between the Tarim Craton and the Siberian Craton (Chen and Pirajno et al., 2011). It is surrounded by the Tian Shan (Boro Horo) and the Bagoda Mountains in the south, the Zaire and Halalate Mountains to the west, and the Qinglid Moun- 
tains and the Karamaili Mountains in the northeast (see Figure 1). The Junggar Basin is sub-divided into four tectonic units from south to north: piedmont depression, central depression, Luliang uplift, and Wulungu depression south of the Qinglid Mountains (see Figure 1). The maximum thickness of the sedimentary filling is $14 \mathrm{~km}$, formed since the Permian and is located in the south of the basin (Zhaohui Tang and Fre, 1997). The age and nature of the basement in the Junggar Basin have been studied from the differing perspectives of geology, geophysics, and geochemistry, but these aspects are still under debate. The basement of the Junggar Basin consists of crystalline rocks (Xu and Li et al., 2015), comprising Paleozoic oceanic crust and island arc systems (Carroll and Graham et al., 1995; Chen and Jahn, 2004; Xiao and Windley et al., 2009). The study area is in the eastern part of the Junggar Basin, bounded by the Karamaili Mountains in the north, the Bagoda Mountains in the south, and connected with the central depression and Luliang uplift in the west (see Figure 1). The Lower Carboniferous Kalamaili Formation, the Tamugang Formation, and the Songkarsu Formation; the upper Carboniferous Batamayineishan Formation and Shuangjingzi Formation, and Permian, Triassic, Jurassic, and Quaternary strata are widely exposed in the study area (see Figure 2). The Batamayineishan Formation has unconformable contact with the underlying Tamugang and Songkarsu Formations and crops out on the northern side of the Karamaili Ophiolite belt. The upper contact is conformable with the Shuangjingzi Formation. The volcanic rocks of Batamayineishan Formation are mainly composed of intermediate to acidic volcanic lava and corresponding pyroclastic rocks and vary in thickness from hundreds of meters to several kilometers. The Batamayineishan Formation is the main development horizon of volcanic rocks in the Junggar Basin. At present, the Carboniferous volcanic oil and gas reservoirs are mainly concentrated in this horizon.

\section{Methods}

Thin-section microscopy, petrophysical properties, and pressure-controlled mercury injection (PMI) on samples were used to analyze the Batamayineishan Formation volcanic reservoir.

Thin-section observations were performed on 42 samples taken directly from outcrops of the Batamayineishan Formation in the Shuangjingzi area: 16 basalt samples, 11 rhyolite samples, 10 breccia samples, and 5 andesite samples were obtained. Microscopic studies were conducted on these thin sections using a petrographic microscope (Olympus BX51) to identify the mineral composition and textural characteristics of different minerals. The thickness of the thin section was 0.3 $\mathrm{mm}$, and the size was $25 \mathrm{~mm} \times 25 \mathrm{~mm}$. Then, 25 thin sections were impregnated with blue dye resin to assess the different types of pore spaces.
The porosity and permeability were measured by petrophysical analysis of 15 volcanic rock samples. The sample was prepared in a small cylindrical shape with a length of $50 \mathrm{~mm}$ and a diameter of $25 \mathrm{~mm}$. Porosity and helium permeability were determined using an automatic permeability analyzer instrument. Test standards (SY/ T-5336-2006), used in the oil and gas industry of China, were followed. These measurements were conducted at a temperature of $20^{\circ} \mathrm{C}$ and humidity of $45 \%$.

PMI was used for 17 samples to characterize different pore structures and pore throat analyses. The equipment used for PMI was an AutoPoreIV9505 mercury porosimeter following the SY/T 5346-2005 standard of China. The test temperature was $19.3^{\circ} \mathrm{C}$, and the humidity was $24 \%$. Mercury was injected into all the available pore spaces using a mercury porosimeter. Based on the pore volume percentage of injected mercury and the corresponding pressure, various key results were obtained regarding pore characteristics, such as mercury intrusion and extrusion curves, average pore throat radius, maximum pore throat radius, and maximum mercury saturation. Capillary pressure curves reflecting several parameters were utilized to study pore throat structures.

After petrographic analysis, the samples with developed amygdales were selected. A JXA-8230 electron probe instrument was used to analyze the mineral composition of different fillings of amygdales and determine the type and composition of the filling minerals. During the test, the accelerating voltage was $20 \mathrm{kV}$, and the electron beam current was $2 \times 10^{-8} \mathrm{~A}$.

\section{Results}

\subsection{Lithology}

The lithological characteristics of the volcanic rocks of the Batamayineishan Formation were determined through outcrop sample description and thin-section observations. The volcanic rock types in the study area include lava, volcanic breccia, and volcaniclastic rocks. The lava has been further divided into basalt, andesite, rhyolite, and dacite in proportions of $39 \%, 12 \%, 23 \%$, and $7 \%$, respectively. Volcanic breccia includes basaltic breccia and rhyolitic breccia in proportions of $14 \%$ and $5 \%$, respectively. Based on the textural structure, volcaniclastic rocks consist of variegated agglomerates and conglomeratic basaltic breccias. Basalt exhibits the overall porphyritic texture and can be divided into trachybasalt and vesicular basalt. Andesite exhibits a porphyritic texture with interleaved structures and argillization of plagioclase phenocrysts. Rhyolite presents spherulites and flow structures and can be divided into vesicular rhyolite and granulated rhyolite. In terms of rock types, lava is widely distributed in the observed thin sections, accounting for $81 \%$ of the composition, while the abundance of volcanic breccia is $19 \%$. 


\subsection{Petrophysical characteristics}

Generally, different rock types exhibit different physical properties owing to variations in their structures and

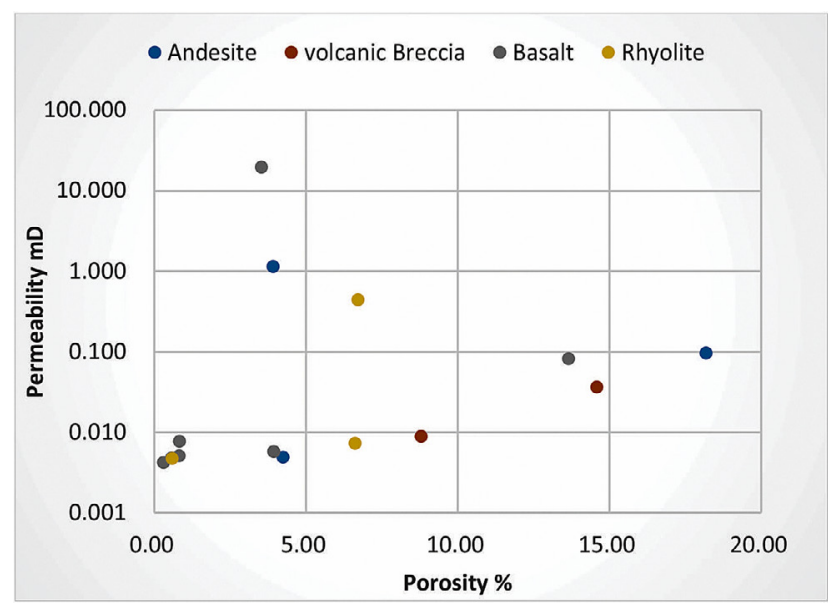

Figure 3 Cross-plot of porosity vs. permeability, showing the volcanic reservoir property of the Carboniferous Batamayineishan Formation in the Shuangjingzi area. For samples of analysed lavas and volcanic breccias. textures. The volcanic rocks of the Batamayineishan Formation are characterized by low porosity, as the measured helium porosity of rock samples is distributed between $0.03 \%$ and $18.18 \%$ with an average value of $5.82 \%$; the measured permeability ranges as 0.004 $19.7 \times 10^{-3} \mu \mathrm{m}^{2}$ with an average value of $1.437 \times 10^{-3} \mu \mathrm{m}^{2}$ (see Figure 3).

To evaluate the reservoir potential of volcanic rocks, it is a prerequisite to identify different lithological types and various reservoir spaces as well as the set of geological processes they have undergone (Sruoga and Rubinstein, 2007). Thin-section observations indicate three types of pore systems in the Batamayineishan Formation, including primary pores, secondary pores, and fractures. The primary pore system includes gas pores, corrosion pores, intergranular pores, and shrinkage cracks. Dissolution pores and intergranular micropores dominate the secondary pore system, while fractures are generated by dissolution and tectonics.

Gas voids are widespread in basalt, rhyolite, and breccias infilled with calcite, zeolite chlorite, and other minerals. These pores are of different shapes and sizes, ranging from round, elongated, and other irregular shapes.

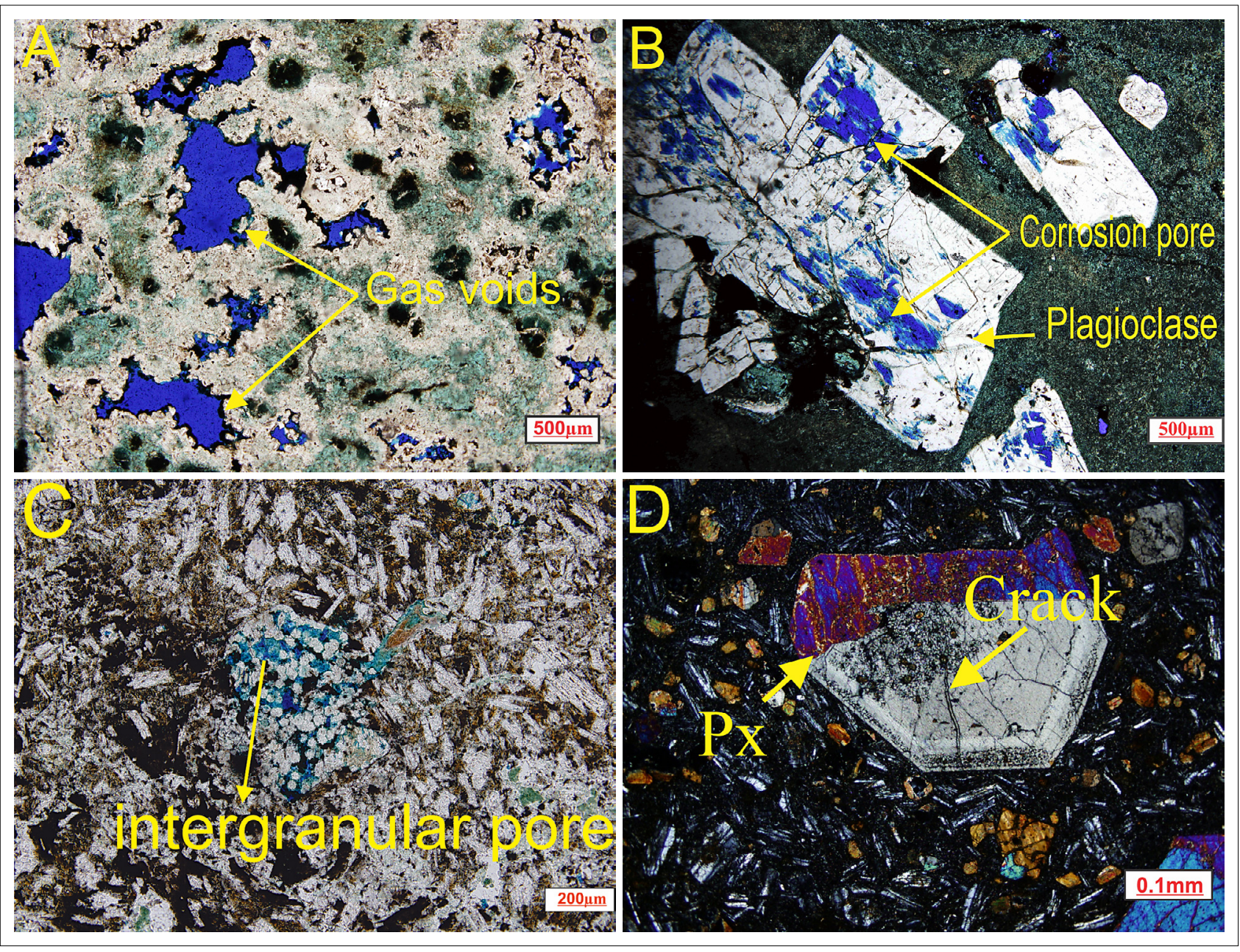

Figure 4 Photomicrographs of primary pores from thin sections of the Batamayineishan volcanic reservoir. A Gas voids in rhyolite, PPL; B Corrosion pore in plagioclase phenocrysts of andesite, PPL; C Intergranular pore in basaltic breccia, PPL; D Cracks in pyroxene phenocryst of basalt, XPL. 


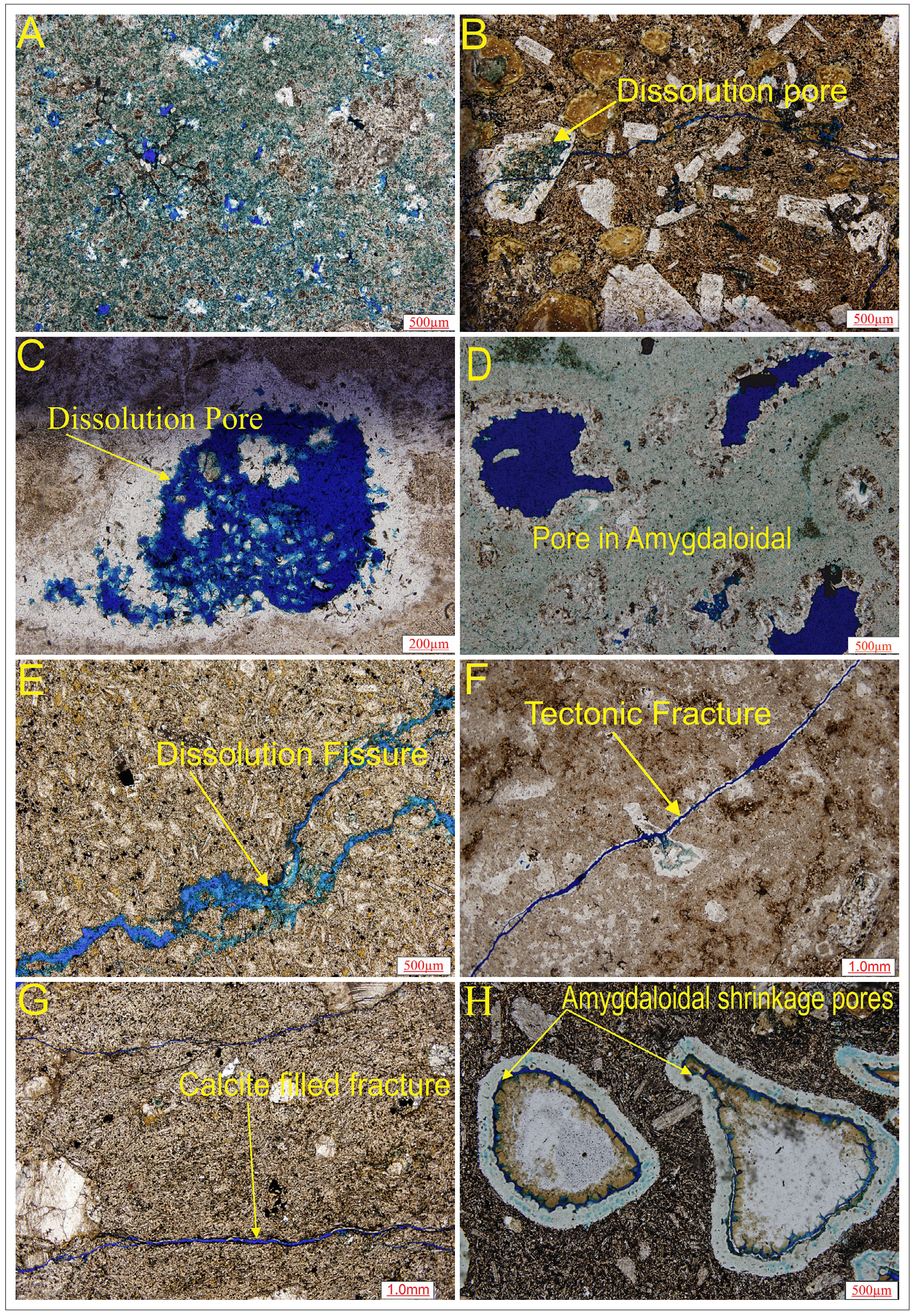

Figure 5 Photomicrographs of secondary pores and fractures from thin sections of the Batamayineishan volcanic reservoir. A Intercrystalline micropore in andesite, PPL; B Dissolution pore in feldspar phenocryst of basalt PPL; C Amygdaloidal dissolved pore in rhyolite, PPL; D Amygdaloidal shrinkage pore in basaltic breccia, PPL; E Dissolution fissure in andesite, PPL; F Tectonic fracture in rhyolite, PPL; $\mathbf{G}$ Calcite filled fracture in basalt; $\mathbf{H}$ Pore in amygdaloidal basalt, PPL. 

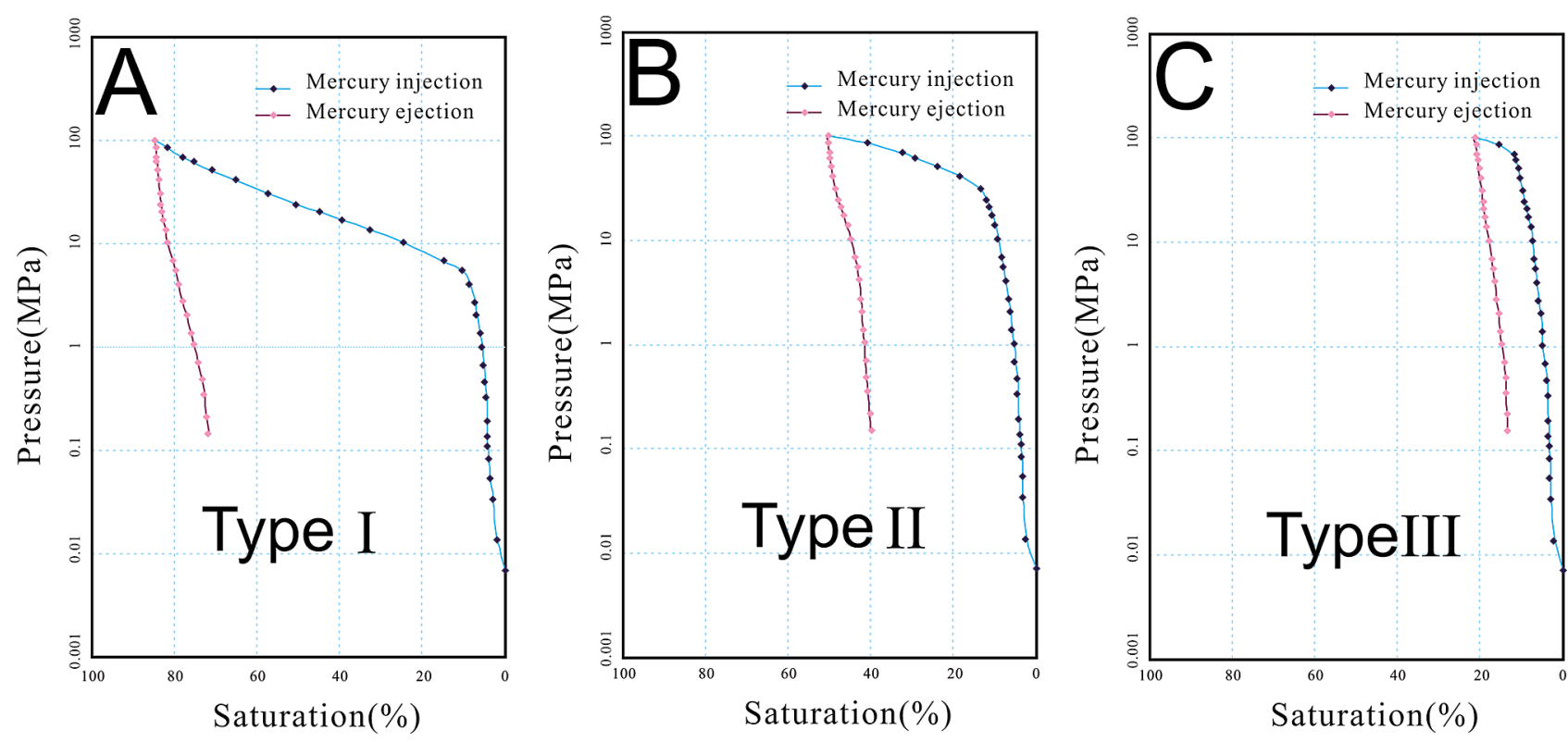

Figure 6 Three types of capillary pressure curves for the Carboniferous volcanic rocks of the Batamayineishan Formation in the ShuangJingZi area, eastern Junggar.

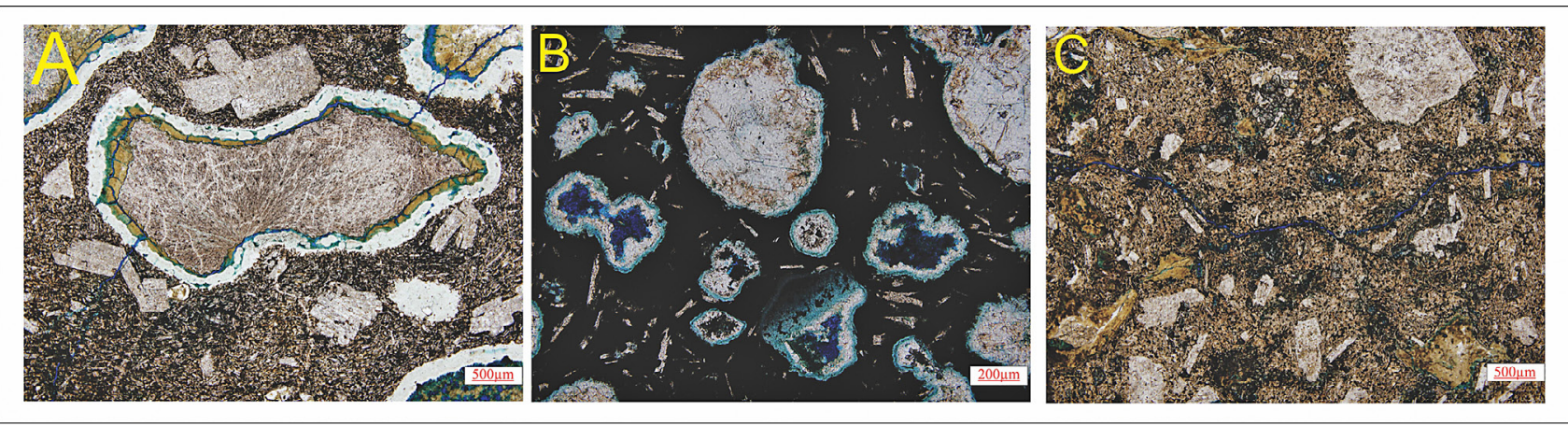

Figure 7 Type I pore structures. A Amygdaloidal shrinkage cracks in basaltic breccia, PPL; B Dissolved pore in rhyolite, PPL; C Fracture in vesicular basalt, PPL.

When connected with shrinkage cracks, dissolution occurs and can form a potential reservoir space (see Figure 4A). Corrosion pores primarily occur in andesite and rhyolite, especially within the feldspar phenocrysts of andesite (see Figure 4B). Intergranular pores formed in basaltic breccia and volcaniclastic rock (see Figure 4C) cracks mainly develop in basalts, especially in pyroxene phenocrysts (see Figure 4D).

Intercrystalline micropores are commonly observed in andesite and rhyolite; they are formed as a result of devitrification of volcanic glass during the process of vitrification. Although the pores are irregular and small, they are clearly visible as indicated by the blue areas (see Figure 5A). Dissolution pores are widely developed in volcanic rocks of the Batamayineishan Formation, and according to differences in development position, can be divided into phenocrysts dissolution pores (see Figure 5B) and solution pores in amygdales (see Figures 5C, 5D). Gas pores develop and are filled with secondary minerals to form amygdales. A portion of the amygdales dissolve and form a secondary reservoir space. Vesicles infilled by minerals condense and contract after infilling, and amygdaloidal shrinkage pores form between the filling and pore wall (see Figure 5H). Dissolution fissures are developed in basalt and are characterized by jagged and irregular surfaces (see Figure $\mathbf{5 E}$ ). Tectonic fractures with lengths of several millimeters to a few centimeters (see Figures 5F, 5G) pass through the amygdale (see Figure 5F) or parallel to each other (see Figure 5G).

\subsection{Pore structure of reservoir rock}

In volcanic reservoirs, variable pore and throat structures are key factors in controlling the migration and accumulation of hydrocarbons and determining the reservoir potential of volcanic rocks (Huang., 2019; Zhang, 2017). The results of mercury injection indicate that the average pore throat radius and porosity of the volcanic rocks are $0.068 \mu \mathrm{m}$ and $6.62 \%$, respectively. The average value of permeability is $0.424 \times 10^{-3} \mu \mathrm{m}^{2}$, which typically suggests narrow micro-throats and contributes significantly to low 

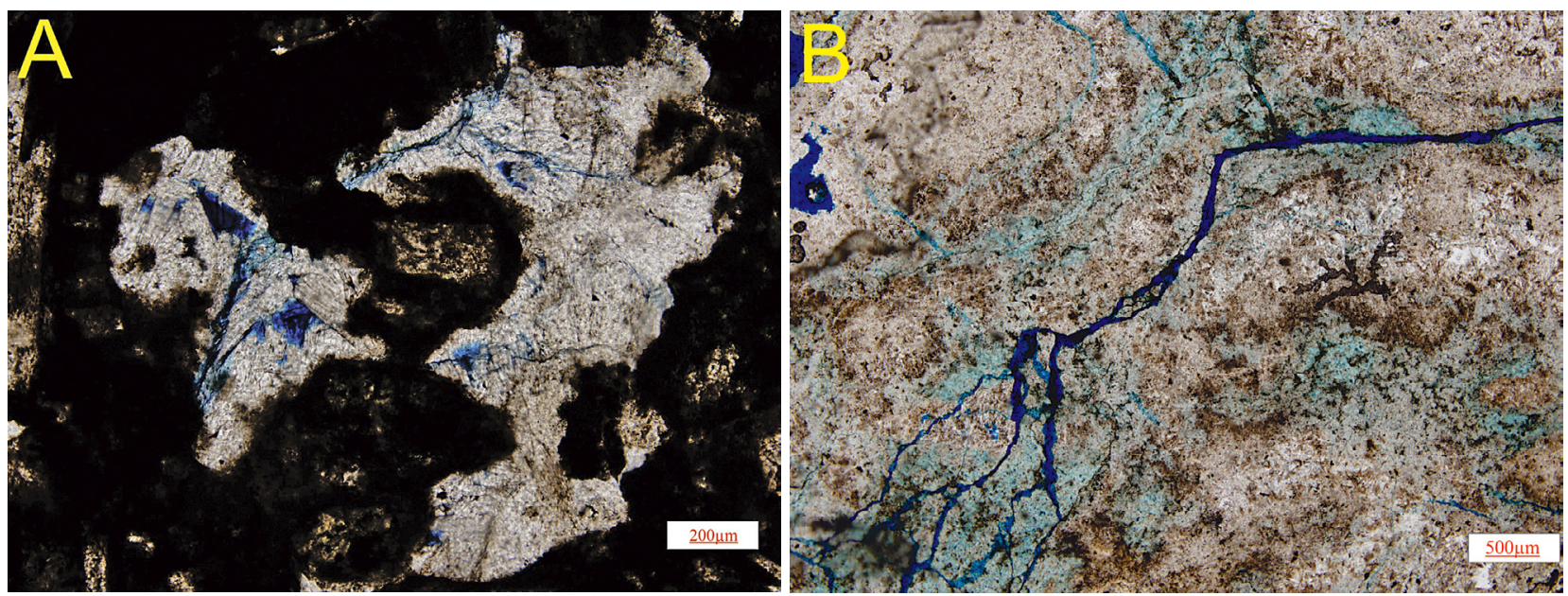

Figure 8 Type II pore structures. A Dissolution pore in basaltic breccia, PPL; B Dissolution cracks and fracture in rhyolite, PPL.
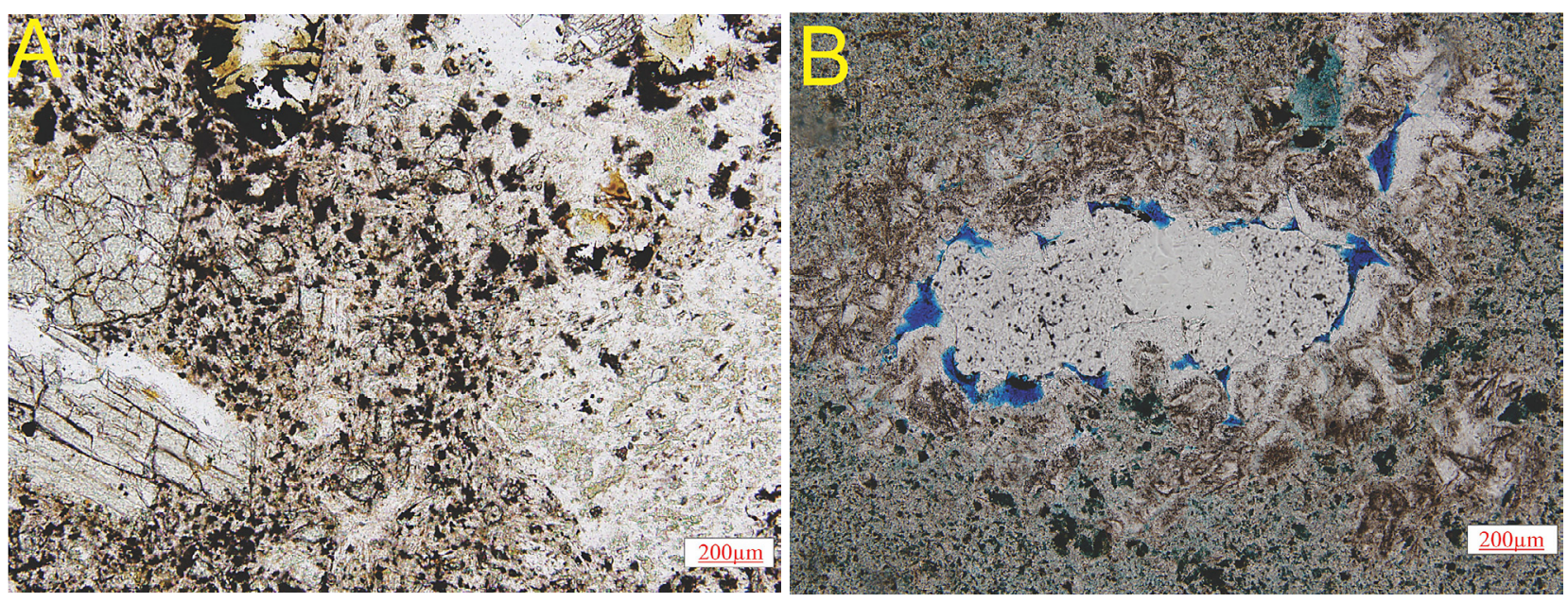

Figure 9 Type III pore structures. A Matrix intergranular pore in basalt, PPL; B Devitrified micropore, dissolved pores in andesite, PPL.

reservoir permeability. The displacement pressure and mercury withdrawal efficiency are considered important parameters for controlling hydrocarbon migration and evaluating reservoir quality. The displacement pressure varies from 0.466 to $68.913 \mathrm{MPa}$, while the mercury withdrawal efficiency varies between $14.375 \%$ and $93.708 \%$, with an average value of $50.57 \%$. The capillary pressure curves of the Carboniferous Batamayineishan Formation can be classified into three types (see Figure 6).

The Type I capillary pressure curve is platformshaped, which shows a low displacement pressure (3.79 $\mathrm{MPa}$ ) and narrow pore throat sorting (see Figure 6A). The average pore throat radius varies between 0.016$0.143 \mu \mathrm{m}$, and pore throats are well connected. There is high-maximum mercury saturation with an average value of $84.20 \%$ and mercury withdrawal efficiency of $70.66 \%$. Type I is mainly distributed in basaltic breccia, rhyolite, and vesicular basalt. The combination of amygdaloidal shrinkage pores with phenocryst solution pores (see Figure 7A) occurs in basaltic breccia. In contrast, primary gas voids and secondary amygdaloidal dissolution pores can be found in rhyolite (see Figure 7B), and fractures dominate the vesicular basalt (see Figure 7C). The average porosity and permeability of the corresponding volcanic rocks are $10.60 \%$ and $0.661 \times 10^{-3}$ $\mu \mathrm{m}^{2}$, respectively, representing the optimal pore structure type for oil reservoirs.

The Type II capillary pressure curve shows no obvious platform, with medium to high displacement pressure ( $34.44 \mathrm{MPa})$, and the sorting of pore throats is poor and not well connected (see Figure 6B). The median maximum mercury saturation is $50-64 \%$, and the mercury withdrawal efficiency is $39.07 \%$. Type II is commonly found in basaltic breccia and rhyolite. Basaltic breccia is dominated by dissolution pores and fractures (see Figure 8A), whereas rhyolite encompasses dissolution cracks and tectonic fractures (see Figure 8B). Type II volcanic rocks are characterized by medium to high reservoir quality, e.g., porosity is $1.84 \%-6.29 \%$ with permeability varying as $0.014-0.635 \times 10^{-3} \mu \mathrm{m}^{2}$. 

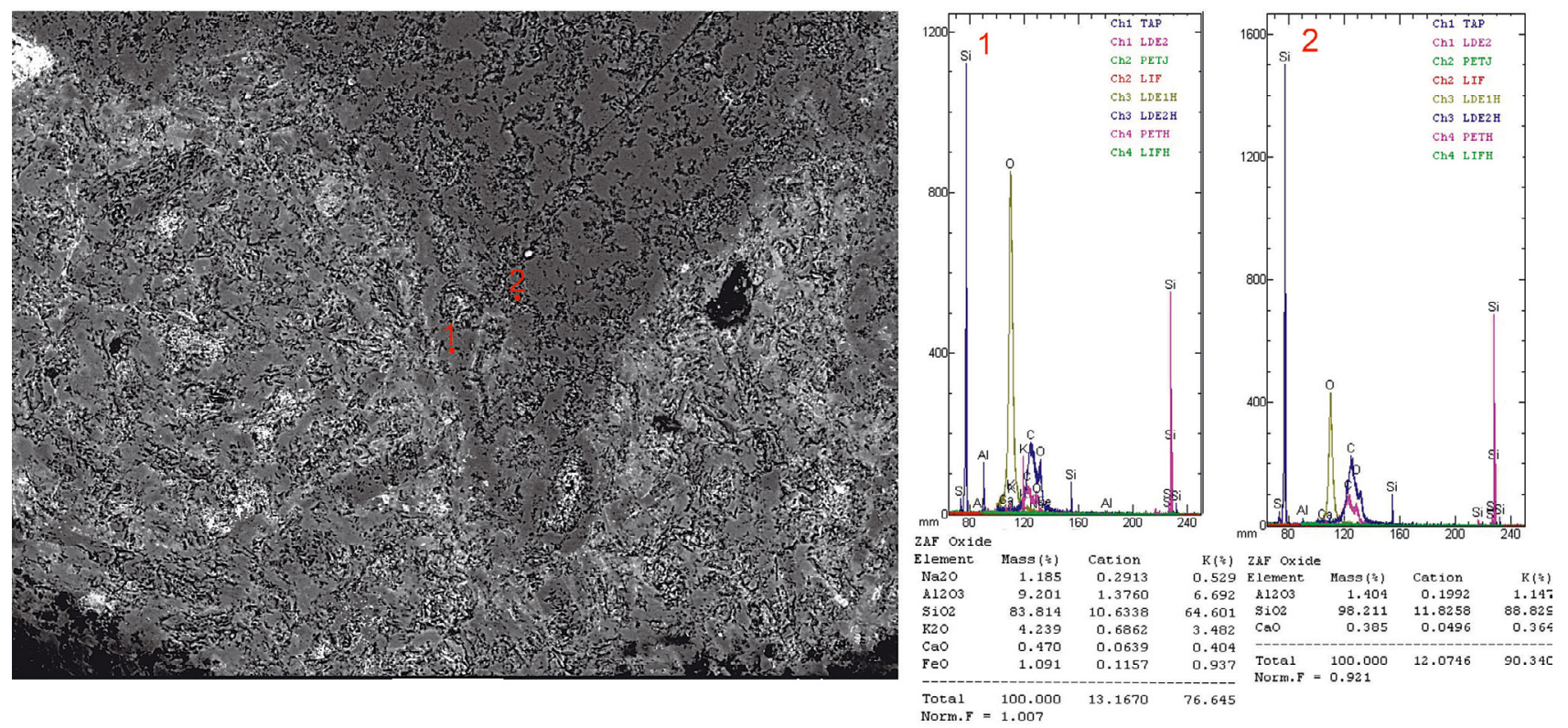

Figure 10 Single component amygdale; composition of each filling phase, which is $\mathrm{SiO}_{2}$, is consistent

The Type III capillary pressure curve is slope shaped, with high displacement pressure $(68.90 \mathrm{MPa})$ and the worst pore throat sorting (see Figure 6C); the mercury withdrawal efficiency is $16.95 \%$. This pore structure type corresponds to poor reservoir quality with porosity and permeability of less than $0.84 \%$ and $0.016 \times 10^{-3} \mu \mathrm{m}^{2}$, respectively. Type III is developed in basalt and andesite. Basalt comprises a matrix of intergranular pores with poor connection (see Figure 9A), while the pore systems in andesites comprises devitrified micropores and matrix dissolved pores (see Figure 9B).

\section{Filling of reservoir spaces in the Batamayineishan Formation}

The amygdale is formed because the primary reservoir spaces (vesicles) in volcanic rocks are filled with secondary minerals. According to the difference in filling mineral composition, amygdales can be divided into single component amygdales and complex component amygdales. According to the different filling minerals, the single component amygdale can be divided into siliceous amygdales and zeolite amygdales, while the complex component amygdale can be divided into several types according to the different mineral assemblages. Different researchers have studied amygdales and have presented different genetic theories regarding filling patterns (Gilg and Morteani et al., 2003; Duarte and Hartmann et al., 2009; Triana $R$ and Herrera $R$ et al., 2012). As one of the main factors determining the characteristics of volcanic reservoirs, diagenesis includes early and late-stage diageneses. Early-stage diagenesis occurs before the condensation and consolidation of rocks, which mainly affects the development of primary pores. In contrast, late-stage diagenesis occurs after con- densation and consolidation, which affects the development of secondary pores. The diagenesis of volcanic reservoirs in the Batamayineishan Formation and filling of reservoir spaces have an obvious destructive effect on the physical properties of volcanic reservoirs (Sruoga and Rubinstein, 2007). Therefore, the study on the origin of the amygdale in the Batamayineishan Formation is not only theoretically significant, but also has practical significance for petroleum exploration.

\subsection{Reservoir space filling types}

Based on the hand specimen identification, thin-section observations, and electron microprobe analysis, it is determined that the volcanic rock pore filling is widely developed in the volcanic rocks of the Batamayineishan Formation, and the filling types vary. The filling products include a single component amygdale and a complex component amygdale. The main filling minerals are quartz, zeolite, calcite, chlorite, saponite, etc.

\subsubsection{Single component amygdale}

Quartz is present in single component amygdales. The quartz amygdale can be filled in many stages. Two filling phases can be identified according to the different colors of filling materials in the vesicle, and the composition of each filling phase, which is $\mathrm{SiO}_{2}$, is consistent (see Figure 10).

\subsubsection{Compound amygdale}

Compared with the single component amygdale, the compound amygdale is more common in the volcanic rocks of the Batamayineishan Formation. According to the different mineral compositions, the compound amyg- 

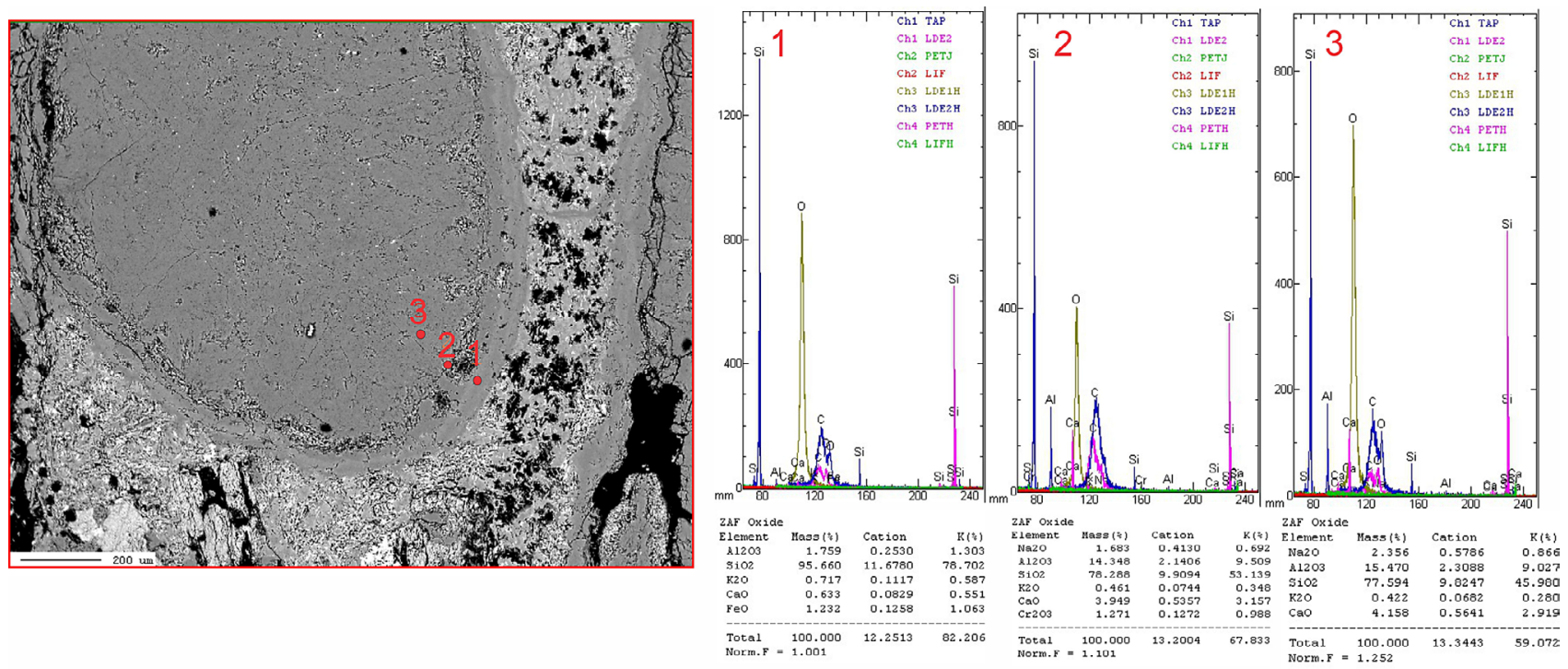

Figure 11 Compound amygdale. Filling minerals are quartz and analcite
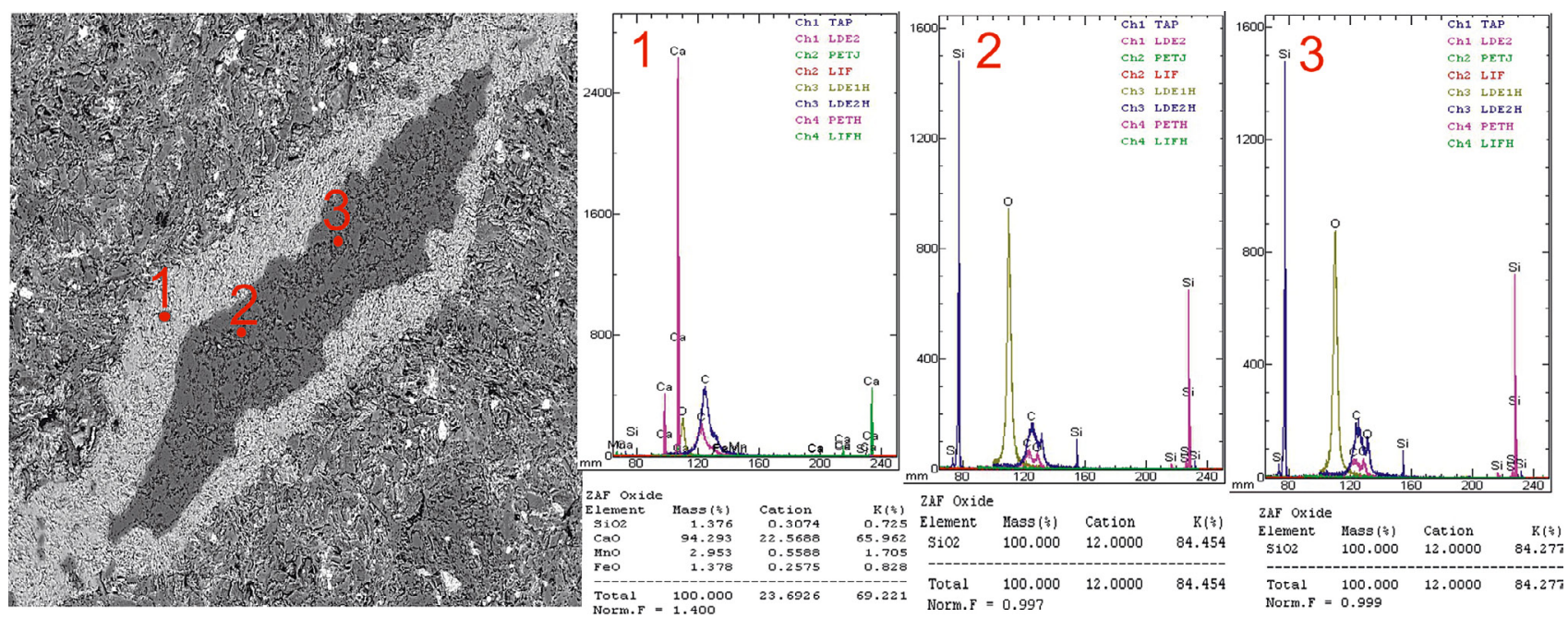

Figure 12 Compound amygdale. Filling minerals are calcite and quartz
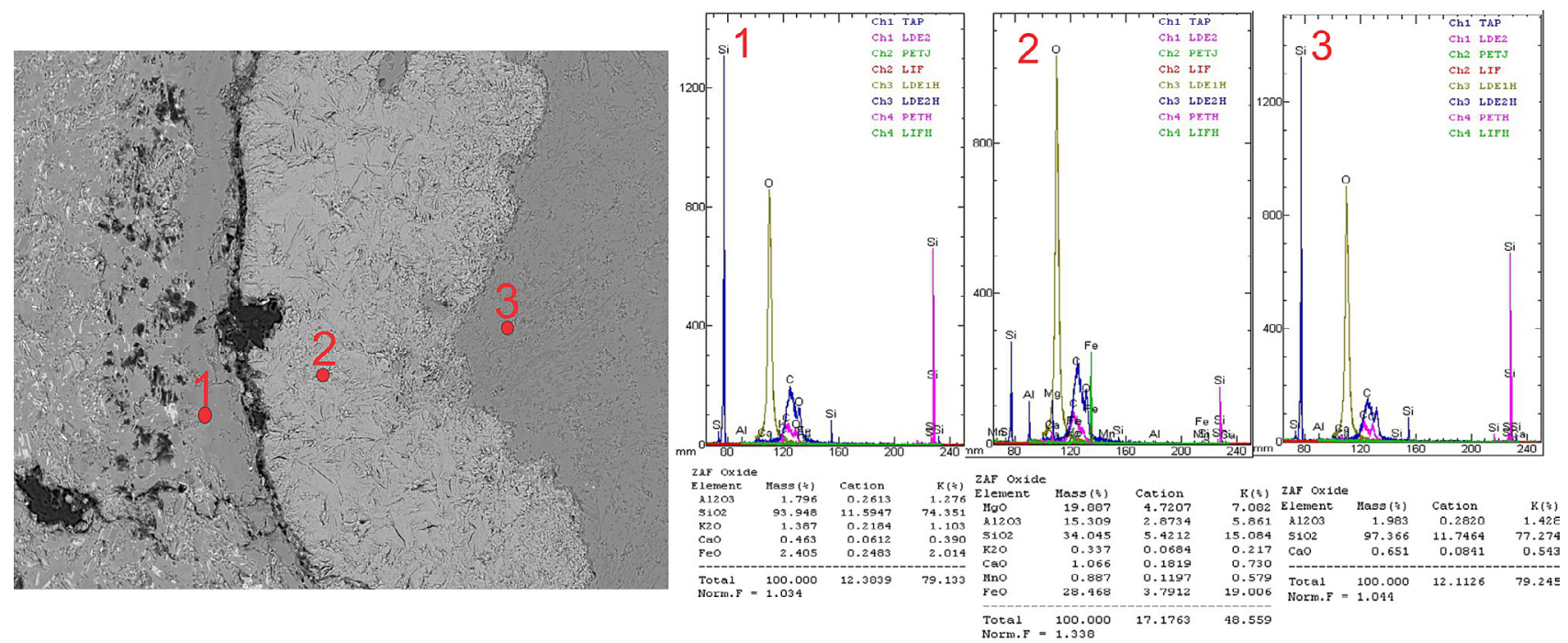

Figure 13 Compound amygdale. Filling minerals are quartz, saponite, and quartz 

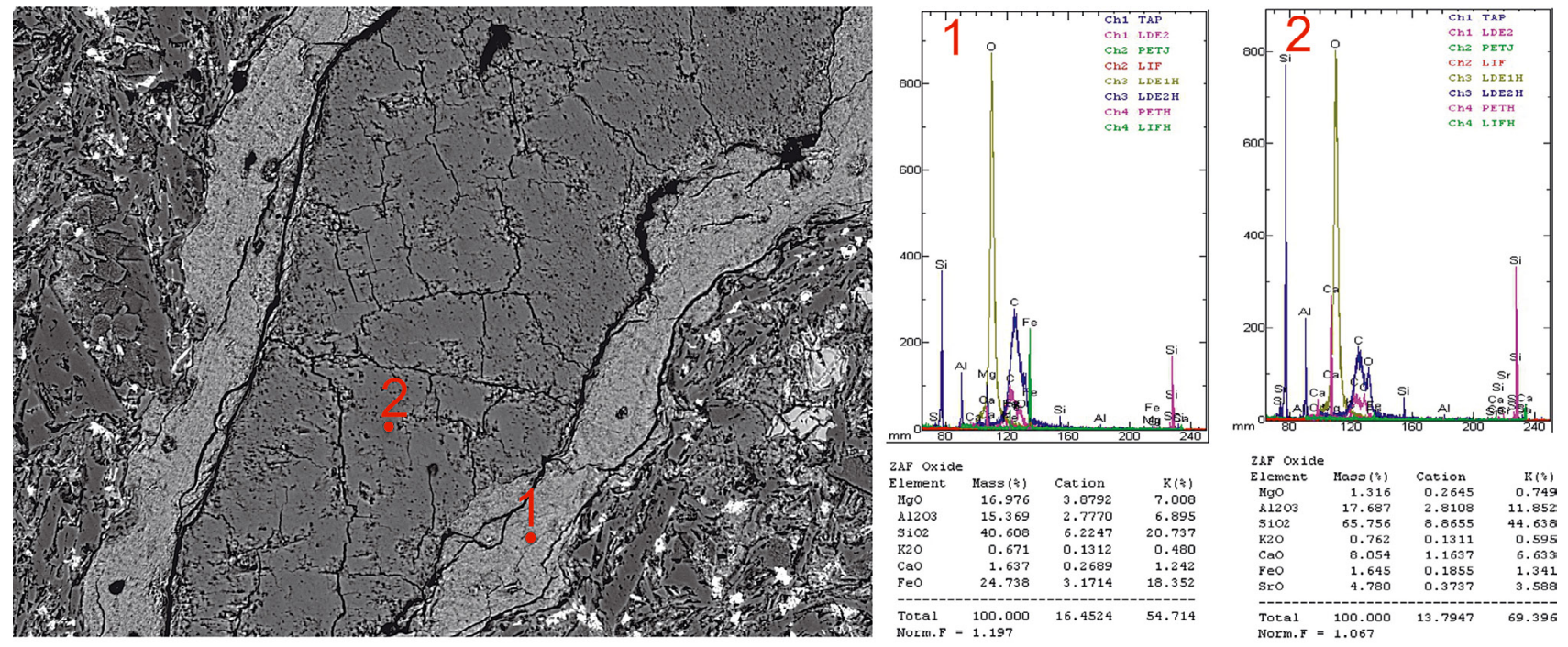

Figure 14 Compound amygdale. Filling minerals are saponite and zeolite
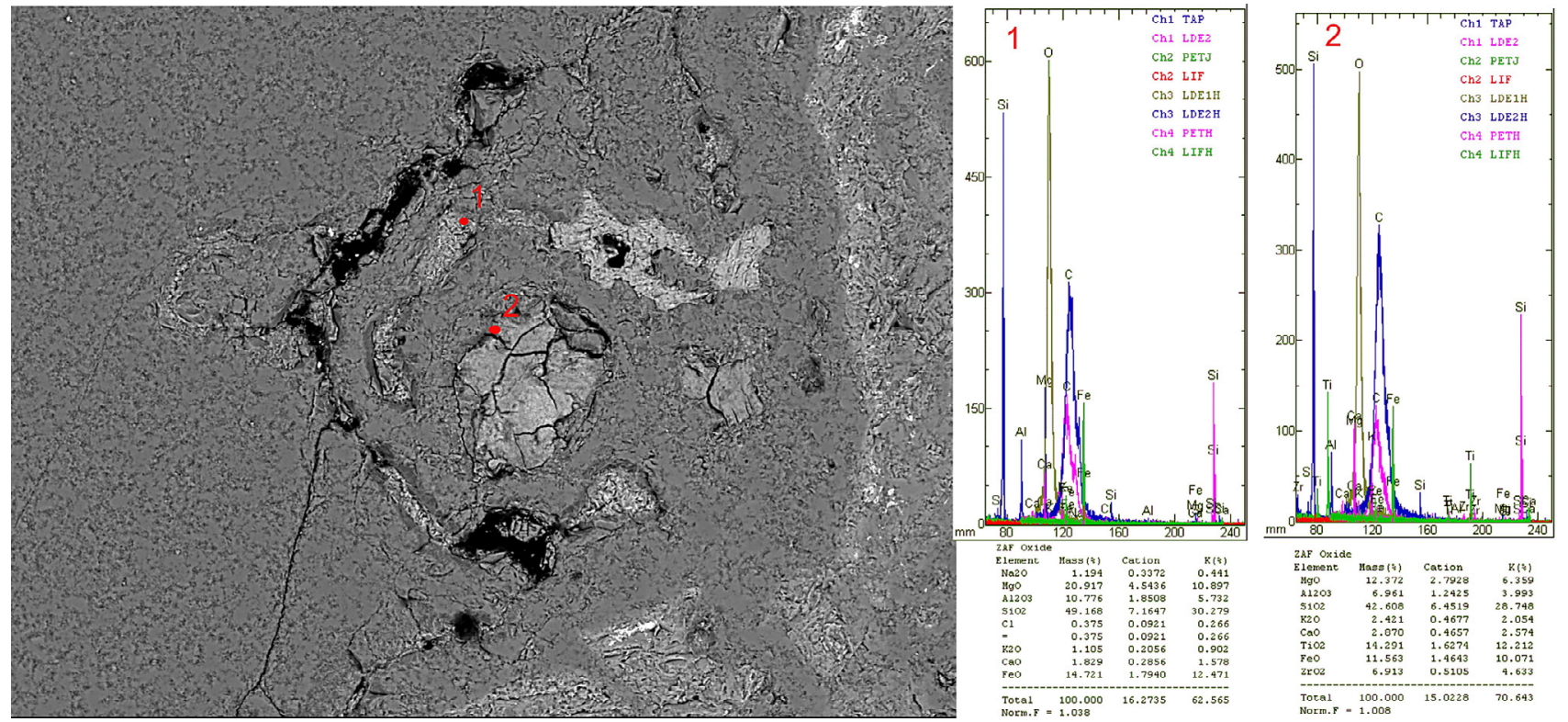

Figure 15 Compound amygdale. Filling minerals are turquoise and saponite

dale of the volcanic rocks of Batamayineishan Formation is divided into the following five types:

1) Quartz $\rightarrow$ Analcite

From the amygdale wall to the center, the filling minerals are quartz and analcite. The quartz is microcrystalline and grows close to the pore wall, whereas the analcite is radial (see Figure 11).

2) Calcite $\rightarrow$ quartz

The filling minerals are calcite and quartz. Calcite has a darker color, which may be due to a small amount of $\mathrm{Mn}$ and Fe. Quartz can be divided into two phases according to color, and both phases are composed of $\mathrm{SiO}_{2}$ (see Figure 12).

3) Quartz $\rightarrow$ saponite $\rightarrow$ quartz

The colorless microcrystalline quartz grows close to the amygdale wall, the soil gray radial quartz grows in the middle of the amygdale, and the yellow aggregate saponite grows between these (see Figure 13). Electron microprobe analysis shows that quartz contains a small amount of $\mathrm{Al}, \mathrm{Ca}$, and $\mathrm{Fe}$.

4) Saponite $\rightarrow$ zeolite

Saponite grows along the amygdaloid body wall, and its interior is a zeolite. The color of saponite is brown, and the zeolite is dense (see Figure 14).

5) Turquoise $\rightarrow$ saponite

The amygdale wall is a radial turquoise, and the interior is filled with saponite, which is in the form of aggregates (see Figure 15).

\section{Discussion}

Previous research has documented that pore networks developed in volcanic rocks by a combination of differ- 
ent pore spaces and generally present no obvious relationship between porosity and permeability; thus, it is difficult to predict the porosity and permeability of volcanic reservoirs (Fisher and Smith, 1991; Jinglan and Chengli et al., 1999). The heterogeneity in the pore throat of volcanic reservoirs can be reported using various parameters (Sruoga and Rubinstein et al., 2004; Feng, 2008). Numerous investigations on volcanic rocks reveal a wide range of porosity and permeability $3 \%-$ $90 \%$ and $10^{-17}-10^{-18} \mathrm{~m}^{2}$ (Mueller and Melnik et al., 2004; Wright and Roberts et al., 2006; Bernard and Zamora et al., 2007; Sruoga and Rubinstein, 2007; Bouvet de Maisonneuve and Bachmann et al., 2008; Gaunt and Sammonds et al., 2014; Heap and Kolzenburg et al., 2014; Heap and Lavallée et al., 2014; Farquharson and Heap et al., 2015). The reservoir space in volcanic rocks is greatly influenced by a combination of primary and secondary processes. The primary processes mainly involve gas expulsion and compaction. Secondary processes generally include alteration, fracture development, cementation, etc. (Zheng and Sun et al., 2018; Huang and Hu et al., 2019). The measured porosity and permeability values reveal that the volcanic rocks of the Batamayineishan Formation are mediumhigh porosity and low permeability reservoirs. Complex geological factors can result in a severe change in the porosity and permeability of volcanic reservoirs; it is difficult to observe these changes at the microscale (Chen and Wang et al., 2016). The reservoir space in the Carboniferous Batamayineishan Formation is divided into four categories owing to the heterogeneity of volcanic rocks. These rocks are dominated by isolated pores, connected pores, microcracks, and fractures. The connected pores formed effective migration pathways and storage space, while mutually unconnected pores do not allow oil and gas to flow and accumulate.

Outgassing of volatile compounds from magma leads to large-scale development of vesicles in volcanic rocks (Barreto and de Lima et al., 2017). Vesicles in basalt and rhyolite significantly contribute to the development of primary porosity (see Figure 4A). Previous studies (Lenhardt and Götz, 2011; Lenhardt and Götz, 2015) have proposed that volcaniclastic sediments are generally subjected to severe diagenesis that can affect the quality of reservoirs. Several processes, such as dissolution and fracturing, are considered as secondary controls in the reservoir space. Dissolution is an important secondary process involved in enhancing the reservoir space. Dissolved pores are formed by the dissolution of a matrix or phenocrysts when volcanic material undergoes compaction, crystallization, and dissolution (see Figures 5B, 5C), whereas precipitation of secondary minerals in open space to form amygdaloidal structures results in a reduction of reservoir space. Saponification, silicification, and argillization are commonly observed in the volcanic rocks of the study area. Volcanic glass is unstable, and with changes in pressure, temperature, and moisture content, it will automatically be transformed from glassy to microcrystalline and crystalloid; it is mainly found in rhyolite (see Figure 5A).

Tectonic-induced fractures in volcanic rocks play a crucial role in controlling the effectiveness of storage space in volcanic reservoirs; these fractures are typically characterized by long extensions with straight fracture planes. Tectonic fractures in the Batamayineishan Formation are filled with calcite (see Figures 5F, 5G) and chlorite. The generation or healing of microcracks contributes positively to the evolution of permeability of volcanic rocks with low porosity (Heap and Farquharson et al., 2015; Heap and Reuschlé et al., 2018). Dissolved fractures, formed by the later-stage dissolution of infilled minerals, play a crucial role in enhancing reservoir quality by providing pathways for hydrocarbon migration. The reservoir space of the fracture type includes structural fractures, filling residual structural fractures, and dissolution fractures. In addition, there were a small number of condensation and shrinkage cracks (see Figures 5D). The effective reservoir space of the volcanic rock reservoir of the Batamayineishan Formation is dominated by a secondary reservoir space. Matrix corrosion pores and porphyry corrosion pores are the most common reservoir spaces, and secondary minerals partially or completely fill primary pores. The remaining reservoir space includes the inner pores of amygdales.

The formation process of the volcanic rock amygdale can be divided into two stages: the formation of vesicles and the precipitation and crystallization of fluid in the vesicle (Gilg and Morteani et al., 2003; Duarte and Hartmann et al., 2009), which is the filling process of the vesicles to form the amygdale. Vesicles are formed when the volatiles of molten lava escape with a decrease in temperature and pressure (Gilg and Morteani et al., 2003; Proust and Fontaine, 2007). When the molten lava is ejected to the surface, it is often distributed in the upper part of the lava flow and is accompanied by many volatiles (Aubele and Crumpler et al., 1988). Gas voids provide space for the formation of the amygdale, while microcracks can serve as a material transport channel for forming the amygdale.

There are several opinions regarding the formation of the amygdale. The amygdale is formed by magmatichydrothermal precipitation and crystallization in a closed system. The required ions are derived from the migration of elements under the high temperature and high pressure of the amygdale host rock. Alteration halos are usually observed at the edges of the amygdale (Proust and Fontaine, 2007). According to (Gilg and Morteani et al., 2003; Duarte and Hartmann et al., 2009), the amygdale is formed by precipitation and crystallization of the epigenetic fluids, with the dissolution or erosion of the host rock by the epigenetic fluids providing the various ions required.

In the geological history of more than 300 million years, different degrees of alteration have occurred, and 
the occurrence of alteration is accompanied by dissolution (Sruoga and Rubinstein, 2007). This is consistent with the characteristics of the host rock of the amygdale in the study area, that is, a large number of alterations and dissolutions occur. Several alteration phenomena, such as plagioclase claynization, pyroxene chloritization, and olivine saponification, can be observed under plain polarized light.

The porosity of the Carboniferous Batamayineishan Formation is not positively correlated with permeability, and the relationship between them is not obvious. The permeability remains stable and does not show a significant change with an increase in porosity (see Figure 3). Despite the high porosity, the permeability is relatively low, reflecting isolated and non-connected primary pores. Samples with directly related changes in porosity and permeability indicate good sorting and the development of microfracture/cracks. This shows a good connection between the pores and fractures.

\section{Conclusions}

The lithology of the Carboniferous Batamayineishan Formation in the Shuangjingzi area, eastern Junggar, predominantly consists of lava with volcanic breccia and volcaniclastic rocks. Three distinctive pore types were recognized: primary, secondary, and fractures. Primary gas vesicles are abundantly developed in volcanic lavas, such as vesicular basalt and vesicular rhyolite. These vesicles are gradually filled to form amygdaloidal structures. Secondary porosity, especially dissolution pores, dissolution fractures, and tectonic fractures, enhances and modifies the petrophysical properties of volcanic rocks. The average values of porosity and permeability were $5.82 \%$ and $1.437 \times 10^{-3} \mu \mathrm{m}^{2}$, respectively. The volcanic rock samples with the highest porosity were mainly volcanic breccia (average: $11.69 \%$ ), followed by andesite (average 8.78\%) and rhyolite (average 4.64\%). Basalt exhibits the lowest porosity and permeability, with average values of $3.38 \%$ and $2.83 \times 10^{-3} \mu \mathrm{m}^{2}$, respectively. Three major types of pore structures were identified by examining the capillary pressure curves. Type I pore structure is mainly distributed in vesicular basalt, basaltic breccia, and rhyolite. Capillary pressure curves are characterized by a low displacement pressure, high mercury saturation, and high mercury ejection. The average throat radius was $0.052 \mu \mathrm{m}$ and showed a good correlation with permeability. Type II pore structure is commonly found in basaltic breccia and rhyolite. The corresponding capillary pressure curves are characterized by medium- to high-performing pore structure types. Type III pore structures are commonly developed in basalt and andesite. Unlike Type I and Type II, Type III capillary pressure curves display a high displacement pressure with the lowest maximum mercury saturation and mercury ejection.
The pore-filling minerals of volcanic rocks in the Batamayineishan Formation include quartz, calcite, zeolite, chlorite, and saponite. It can be divided into single component amygdales and complex component amygdales, with complex component amygdales as the main component, while single component amygdales are rare. The development of microfractures provides space and material migration paths for the formation of the amygdale. Filling worsens the quality of the volcanic reservoir, and the majority of the original gas reservoir space is lost. After the pores were filled, the remaining pores in the amygdale, such as the shrinkage pores, retained the ability of storage. In addition, the dissolution pores produced by dissolution and alteration compensated for the decrease in the original gas pore volume.

\section{Acknowledgment}

We are thankful to the Geological Survey of China for their financial support. This research was funded by the Geological Survey of China under the project No. 1211302108019-1 "Hydrocarbon accumulations in Carboniferous volcanic rocks in Eastern Junggar Basin". We would also like to express our gratitude to the project team, especially “ Mr. Liu Xiaokang, Mr. Wang Lintao, and Mr. Ge Hailong" for their cooperation and support during fieldwork.

\section{References}

Aubele, J. C., L. Crumpler, W. E. J. J. o. V. Elston and G. Research (1988). Vesicle zonation and vertical structure of basalt flows, 35, 4, 349-374.

Barreto, C. J. S., E. F. de Lima and K. Goldberg (2017). Primary vesicles, vesicle-rich segregation structures and recognition of primary and secondary porosities in lava flows from the Paraná igneous province, southern Brazil. Bulletin of Volcanology,79, 4, 31.

Bernard, M.-L., M. Zamora, Y. Géraud and G. Boudon (2007). Transport properties of pyroclastic rocks from Montagne Pelée volcano (Martinique, Lesser Antilles). Journal of Geophysical Research, 112, B5.

Bouvet de Maisonneuve, C., O. Bachmann and A. Burgisser (2008). Characterization of juvenile pyroclasts from the Kos Plateau Tuff (Aegean Arc): insights into the eruptive dynamics of a large rhyolitic eruption. Bulletin of Volcanology, 71, 6, 643-658.

Carroll, A. R., S. A. Graham, M. S. Hendrix, D. Ying and D. Zhou (1995). Late Paleozoic tectonic amalgamation of northwestern China: Sedimentary record of the northern Tarim, northwestern Turpan, and southern Junggar Basins. Geological Society of America Bulletin, 107, 5, 571-594.

Chen, B. and B.-m. Jahn (2004). Genesis of post-collisional granitoids and basement nature of the Junggar Terrane, NW China: Nd-Sr isotope and trace element evidence. Journal of Asian Earth Sciences, 23(5), 691-703.

Chen, Y. J., F. Pirajno, G. Wu, J. P. Qi and X. L. Xiong (2011). Epithermal deposits in North Xinjiang, NW China. International Journal of Earth Sciences, 101, 4, 889-917. 
Chen, Z., X. Wang, X. Wang, Y. Zhang, D. Yang and Y. Tang (2017). Characteristics and petroleum origin of the Carboniferous volcanic rock reservoirs in the Shixi Bulge of Junggar Basin, western China. Marine and Petroleum Geology, 80, 517-537.

Chen, Z., X. Wang, M. Zha, Y. Zhang, Y. Cao, D. Yang, K. Wu, Y. Chen and G. Yuan (2016). Characteristics and formation mechanisms of large volcanic rock oil reservoirs: A case study of the Carboniferous rocks in the Kebai fault zone of Junggar Basin, China. AAPG Bulletin, 100, 10, 1585-1617.

Cui, J., J. Zhang and H. Zhang (2013). Features of the carboniferous volcanic rocks fracture reservoirs in Hongshanzui oilfield, Junggar Basin. Journal of Earth Science 24, 6, 997-1007.

Du, Q., Z. Han, X. Shen, C. Han, M. Han, Z. Song, L. Gao, H. Liu, W. Zhong and J. Yan (2017). Zircon U-Pb geochronology and geochemistry of the post-collisional volcanic rocks in eastern Xinjiang Province, NW China: implications for the tectonic evolution of the Junggar terrane. International Geology Review, 60, 3, 339-364.

Duarte, L., L. Hartmann, M. Vasconcellos, J. Medeiros, T. J. J. o. V. Theye and G. Research (2009). Epigenetic formation of amethyst-bearing geodes from Los Catalanes gemological district, Artigas, Uruguay, southern Paraná Magmatic Province. 184, 3-4, 427-436.

Farquharson, J., M. J. Heap, N. R. Varley, P. Baud and T. Reuschlé (2015). Permeability and porosity relationships of edifice-forming andesites: A combined field and laboratory study. Journal of Volcanology and Geothermal Research, 297, 52-68.

Feng, M., T. Liu, T. Lin, X. Liu, N. Li and A. Xi (2019). Fracture Fillings and Implication of Fluid Activities in Volcanic Rocks: Dixi Area in Kelameili Gas Field, Junggar Basin, Northwestern China. Minerals, 9, 3.

Feng, Z.-q. (2008). Volcanic rocks as prolific gas reservoir: A case study from the Qingshen gas field in the Songliao Basin, NE China. Marine and Petroleum Geology, 25, 4-5, 416-432.

Fisher, R. V. and G. A. Smith (1991). Volcanism, tectonics and sedimentation.

Gaunt, H. E., P. R. Sammonds, P. G. Meredith, R. Smith and J. S. Pallister (2014). Pathways for degassing during the lava dome eruption of Mount St. Helens 2004-2008. Geology, 42, 11, 947-950.

Gilg, H. A., G. Morteani, Y. Kostitsyn, C. Preinfalk, I. Gatter and A. J. J. M. D. Strieder (2003). Genesis of amethyst geodes in basaltic rocks of the Serra Geral Formation (Ametista do Sul, Rio Grande do Sul, Brazil): a fluid inclusion, REE, oxygen, carbon, and Sr isotope study on basalt, quartz, and calcite. Mineralium Deposita, 38, 8, 1009-1025.

Heap, M. J., J. I. Farquharson, F. B. Wadsworth, S. Kolzenburg and J. K. Russell (2015). Timescales for permeability reduction and strength recovery in densifying magma. Earth and Planetary Science Letters, 429, 223-233.

Heap, M. J., S. Kolzenburg, J. K. Russell, M. E. Campbell, J. Welles, J. I. Farquharson and A. Ryan (2014). Conditions and timescales for welding block-and-ash flow deposits. Journal of Volcanology and Geothermal Research, 289, 202-209.
Heap, M. J., Y. Lavallée, L. Petrakova, P. Baud, T. Reuschlé, N. R. Varley and D. B. Dingwell (2014). Microstructural controls on the physical and mechanical properties of edifice-forming andesites at Volcán de Colima, Mexico. Journal of Geophysical Research: Solid Earth, 119, 4, 2925-2963.

Heap, M. J., T. Reuschlé, J. I. Farquharson and P. Baud (2018). Permeability of volcanic rocks to gas and water. Journal of Volcanology and Geothermal Research, 354, 29-38.

Huang, Y., W. Hu, B. Yuan, G. Zhang and L. Bai (2019). Evaluation of pore structures in volcanic reservoirs: a case study of the Lower Cretaceous Yingcheng Formation in the Southern Songliao Basin, NE China. Environmental Earth Sciences, 78, 4, 102.

Jinglan, L., Z. Chengli and Q. J. J. o. P. G. Zhihao (1999). Volcanic reservoir rocks: A case study of the Cretaceous Fenghuadian suite, Huanghua basin, eastern China. Journal of Petroleum Geology, 22, 4, 397-416.

Lenhardt, N. and A. E. Götz (2011). Volcanic settings and their reservoir potential: An outcrop analog study on the Miocene Tepoztlán Formation, Central Mexico. Journal of Volcanology and Geothermal Research, 204, 1-4, 66-75.

Lenhardt, N. and A. E. J. R. E. Götz (2015). Geothermal reservoir potential of volcaniclastic settings: the Valley of Mexico, Central Mexico. Renewable Energy, 77, 423-429.

Mueller, S., O. Melnik, O. Spieler, B. Scheu and D. B. Dingwell (2004). Permeability and degassing of dome lavas undergoing rapid decompression: An experimental determination. Bulletin of Volcanology, 67, 6, 526-538.

Nakata, J. K. (1981). Distribution and petrology of the Anderson-Coyote Reservoir volcanic rocks, California, 80, 1256. US Geological Survey.

Navelot, V., Y. Géraud, A. Favier, M. Diraison, M. Corsini, J.M. Lardeaux, C. Verati, J. Mercier de Lépinay, L. Legendre and G. Beauchamps (2018). Petrophysical properties of volcanic rocks and impacts of hydrothermal alteration in the Guadeloupe Archipelago (West Indies). Journal of Volcanology and Geothermal Research, 360, 1-21.

Petford, N. and McCaffrey, K. (2003). Hydrocarbons in crystalline rocks: an introduction. Geological Society, London, Special Publications, 214, 1, 1-5.

Proust, D. and Fontaine, C. (2007). Amethyst-bearing lava flows in the Paraná basin (Rio Grande do Sul, Brazil): cooling, vesiculation and formation of the geodic cavities. Geological Magazine, 144, 1, 53-65.

Shi, J. a., G. Sun, S. Zhang, H. Guo, S. Zhang and S. Du (2017). Reservoir characteristics and control factors of Carboniferous volcanic gas reservoirs in the Dixi area of Junggar Basin, China. Journal of Natural Gas Geoscience, 2, 1, 43-55.

Sruoga, P. and N. Rubinstein (2007). Processes controlling porosity and permeability in volcanic reservoirs from the Austral and Neuquén basins, Argentina. AAPG Bulletin, 91, 1, 115-129.

Sruoga, P., N. Rubinstein and G. Hinterwimmer (2004). Porosity and permeability in volcanic rocks: a case study on the Serie Tobífera, South Patagonia, Argentina. Journal of Volcanology and Geothermal Research, 132, 1, 31-43. 
Su, Y., J. Zheng, W. L. Griffin, J. Zhao, H. Tang, Q. Ma and X. Lin (2012). Geochemistry and geochronology of Carboniferous volcanic rocks in the eastern Junggar terrane, NW China: Implication for a tectonic transition. Gondwana Research, 22, 3-4, 1009-1029.

Sun, H., D. Zhong and W. Zhan (2018). Reservoir characteristics in the Cretaceous volcanic rocks of Songliao Basin, China: A case of dynamics and evolution of the volcanoporosity and diagenesis. Energy Exploration \& Exploitation, 37, 2, 607-625.

Sun, X., S. Cao, X. Pan, X. Hou, H. Gao and J. Li (2018). Characteristics and prediction of weathered volcanic rock reservoirs: A case study of Carboniferous rocks in Zhongguai paleouplift of Junggar Basin, China. Interpretation, 6, 2, T431-T447.

Triana R, J. M., Herrera R, J. F., Ríos R, C. A., Castellanos A, O. M., Henao M, J. A., Williams, C. D. and Roberts, C. L. (2012). Natural zeolites filling amygdales and veins in basalts from the British Tertiary Igneous Province on the Isle of Skye, Scotland. Earth Sciences Research Journal, 16, 1, 41-53.

Wang, P. and S. Chen (2015). Cretaceous volcanic reservoirs and their exploration in the Songliao Basin, northeast China. AAPG Bulletin, 99, 03, 499-523.

Wright, H. M. N., J. J. Roberts and K. V. Cashman (2006). Permeability of anisotropic tube pumice: Model calculations and measurements. Geophysical Research Letters, $33,17$.

Xiao, W. J., B. F. Windley, B. C. Huang, C. M. Han, C. Yuan, H. L. Chen, M. Sun, S. Sun and J. L. Li (2009). End-Permian to mid-Triassic termination of the accretionary processes of the southern Altaids: implications for the geodynamic evolution, Phanerozoic continental growth, and metallogeny of Central Asia. International Journal of Earth Sciences, 98, 6, 1189-1217.

Xiao, Y., H. Zhang, J. a. Shi, B. Su, P. A. Sakyi, X. Lu, Y. Hu and Z. Zhang (2011). Late Paleozoic magmatic record of East Junggar, NW China and its significance: Implication from zircon $\mathrm{U}-\mathrm{Pb}$ dating and $\mathrm{Hf}$ isotope. Gondwana Research, 20, 2-3, 532-542.
Xu, X. W., Li, X. H., Jiang, N., Li, Q. L., Qu, X., Yang, Y. H., ... and Dong, L. H. (2015). Basement nature and origin of the Junggar terrane: New zircon U-Pb-Hf isotope evidence from Paleozoic rocks and their enclaves. Gondwana Research, 28, 1, 288-310.

Yang, C., L. Hou, F. Yang, X. Luo and J. Wang (2017). Controlling factors of volcanic hydrocarbon reservoirs in Bohai Bay Basin, China. Journal of Natural Gas Geoscience, 2, 4, 219-228.

Yang, X.-F., D.-F. He, Q.-C. Wang and Y. Tang (2012). Tectonostratigraphic evolution of the Carboniferous arc-related basin in the East Junggar Basin, northwest China: Insights into its link with the subduction process. Gondwana Research, 22, 3-4, 1030-1046.

Zhang, Y., Z. Guo, G. Pe-Piper and D. J. W. Piper (2015). Geochemistry and petrogenesis of Early Carboniferous volcanic rocks in East Junggar, North Xinjiang: Implications for post-collisional magmatism and geodynamic process. Gondwana Research, 28, 4, 1466-1481.

Zhaohui Tang, J. P. and Fre (1997). Diagenesis and Reservoir Potential of Permian-Triassic Fluvial/Lacustrine Sandstones in the Southern Junggar Basin, Northwestern China. AAPG bulletin, 81, 1997, 1843-1865

Zheng, H., X. Sun, J. Wang, D. Zhu and X. Zhang (2018). Devitrification pores and their contribution to volcanic reservoirs: A case study in the Hailar Basin, NE China. Marine and Petroleum Geology, 98, 718-732.

Zheng, H., X. Sun, D. Zhu, J. Tian, P. Wang and X. Zhang (2018). Characteristics and factors controlling reservoir space in the Cretaceous volcanic rocks of the Hailar Basin, NE China. Marine and Petroleum Geology, 91, 749-763.

Zou, c. N., Zhao, w. Z., Jia, c. Z., Zhu, r. K., Zhang, g. Y., Xia, Z., and Yuan, X. J. (2008). Formation and distribution of volcanic hydrocarbon reservoirs in sedimentary basins of China. Petroleum Exploration and Development, 35, 3, 257-271.

Zou, C. (2013). Volcanic reservoirs in petroleum exploration ( $1^{\text {st }}$ ed.), Newnes, 12-13. 


\section{SAŽETAK}

\section{Struktura šupljina i svojstva ležišta u vulkanskim stijenama karbonske formacije Batamajinejšan u području Šuangđingzi, istočni dio bazena Junggar (zapadna Kina)}

Bazen Junggar jedan je od najvećih taložnih bazena u sjeverozapadnoj Kini. Karbonska ležišta nafte i plina otkrivena su u različitim dijelovima na istoku toga bazena te pokazuju kako karbonske stijene i dalje imaju velik potencijal za istraživanje ugljikovodika. Studija je usmjerena na istočni dio toga bazena i formaciju Batamajinejšan, koja je izgrađena od vulkanskih i piroklastičnih stijena. Istražena su njihova ležišna svojstva i način oblikovanja tih stijena. Najveći dio ležišnoga volumena obilježen je sekundarnom šupljikavošću i pukotinama. Tijekom istraživanja korištene su petrografske metode, utiskivanje volumena žive pod kontroliranim tlakom, mikroanaliza elektronskom sondom. Na taj su način ispitana dijagenetska povijest i svojstva vulkanita formacije Batamajinejšan. Time je postavljen teorijski okvir svih istraživanja karbonskih vulkanskih stijena u tome bazenu. Utiskivanjem žive izračunan je prosječni promjer šupljina od o,o68 $\mu \mathrm{m}$ i šupljikavost 6,62 \%, međutim propusnost je općenito niska $\left(0,424 \times 10^{-3} \mu \mathrm{m}^{2}\right)$ jer je dominantno rezultat male primarne, efektivne šupljikavosti te se znatno ne mijenja s povećanjem ukupne šupljikavosti, koja i dalje upućuje na mikropore. Sekundarna šupljikavost također je oblikovana i otapanjem, što je, uz pukotine, povećalo dostupan volumen za nakupljanje plina.

\section{Ključne riječi:}

bazen Junggar, formacija Batamajinejšan, vulkansko ležište, šupljikavost, dijageneza, nakupljanje

\section{Author's contribution}

Masab Ali (MS Scholar, Final year student, Petroleum geology) performed the data analysis, investigation, interpretation of the results, and prepared the original draft. Weihua Bian (PhD, Associate Professor, Petroleum geology) provided the necessary field data, ensured funding acquisition, carried out supervision, review and editing. Yang KaiKai (PhD, Lecturer, Petroleum Geology) performed EPMA, interpretation, and presentation of the results. Muhammad Sabeh Khan Panni (MS Scholar, $2^{\text {nd }}$ year, Minerology, petrology and mineral deposits) drew and edited the maps of regional geology and the study area, carried out proofreading, review and editing, and prepared the draft manuscript. All the authors reviewed the results and approved the final version of the manuscript. 